\title{
Nuclear Medicine Procedures for the Evaluation of Male Sexual Organs: A Brief Review
}

\author{
Mario Bernardo-Filho ${ }^{1,2}$, Sebastião David Santos-Filho ${ }^{1}$, Adenilson de Souza da Fonseca ${ }^{1}$, \\ Kevin Carter ${ }^{3}$ and Sotiris Missailidis ${ }^{4}$ \\ ${ }^{1}$ Laboratório de Radiofarmácia Experimental; Departamento de Biofísica e Biometria; Instituto de Biologia \\ Roberto Alcantara Gomes; Universidade do Estado do Rio de Janeiro; 20551-030; Rio de Janeiro - RJ - Brasil. \\ ${ }^{2}$ Coordenadoria de Pesquisa; Instituto Nacional do Câncer; 20230130; Rio de Janeiro - RJ - Brasil. ${ }^{3}$ Department of \\ Radiology; Brigham and Women's Hospital; Harvard University; Boston; MA, 02446 - USA. ${ }^{4}$ Department of \\ Chemistry and Analytical Sciences; The Open University; Walton Hall; Milton Keynes; MK7 6AA - UK
}

\begin{abstract}
Sexuality consists of three aspects that are interrelated and inseparable, biological, physiological and social. The biological aspect considers the individual's capability to give and to receive pleasure. In consequence, it covers the functionality of the sexual organs and the physiology of human sexual response cycle. Diagnostic imaging modalities, such as single photon emission computed tomography (SPECT) and positron emission tomography (PET) have been used to evaluate clinical disorders of the male reproductive system. PET and SPECT procedures basically involve the administration of a radiopharmaceutical that has a higher uptake in a specific tumor or tissue. The aim of this brief review is to present some radiopharmaceuticals that have been used in the clinical evaluation of the male sexual organs (testes, prostate, seminal vesicles, penis) related with male sexuality. This information could be useful in better understanding the male sexual response cycle, as well as the sexual disorders, when considering the male sexual organs and the pelvic floor. Moreover, the findings obtained with PET and SPECT imaging could help to evaluate the efficacy of clinical results of therapeutic procedures. In conclusion, the knowledge from these images could aid in better understanding the physiology of the different organs related with sexuality. Furthermore, they could be important tools to evaluate the physiological integrity of the involved organs, to improve clinical strategies and to accompany the patients under treatment.
\end{abstract}

Key words: Male sexual organs, PET, SPECT, radiopharmaceutical, sexuality

\section{INTRODUCTION}

Sexual activity and the male sexual organs

Sexuality and its expression contribute to some of the most important aspects of human behavior and is a powerful, complex bio-psycho-social process (Miyagawa et al., 2007; Srivastava et al., 2008). Furthermore, sexuality is considered as a personal and human dimension that comprises not only genitality, but extends beyond the limits of the genital impulse. It is characterized as a profound and all-inclusive aspect of human personality, present from the conception until death, including everything that we are and what we do (Melo et al., 2006, Miyagawa et al., 2007).

Sexuality consists of three interrelated and inseparable aspects: biological, physiological and social. The biological aspect considers the individual's capability to give and receive pleasure. In consequence, it covers the

\footnotetext{
Author for correspondence
} 
functionality of the sexual organs and the physiology of human sexual response cycle that comprises desire, excitation, orgasm and resolution (Masters and Johnson, 1970; Kolodny et al., 1979; Dennerstein et al., 2005; Melo et al., 2006).

The human male psychosexual cycle is categorized into four phases according to penodynamic changes: (i) excitement into latency and tumescence, (ii) plateau into erection and rigidity, (iii) orgasm into emission and ejaculation, and (iv) resolution into detumescence and refractoriness. During each phase, the specific response in neural pathway, penile hemodynamics, and functional status occurs. Ejaculation represents a major component of male sexual behavior and, it is typically accompanied by orgasmic sensations (Govier et al., 1995).

Besides the psychosexual reactions, ejaculation is also the result of a coordinated action of a healthy male reproductive system that encompasses several organs such as the testes, prostate, seminal vesicles, ejaculatory ducts, urethra (bulbourethral glands) and penis, and pelvic floor muscles (Govier et al., 1995; Hatzimouratidis and Hatzichristou, 2007). Diseases in these anatomic structures can result in complications related to reproduction, as well as, the cycle of the sexual response. Diagnostic imaging modalities, such as ultrasound, computed axial tomography (CT), magnetic resonance imaging (MRI), single photon emission computed tomography (SPECT) and positron emission tomography (PET), have been used increasingly to evaluate the clinical disorders of the male reproductive system (Futterer et al., 2008).

\section{Nuclear medicine procedures}

One important aspect of nuclear medicine imaging is that this type of imaging demonstrates physiology rather than anatomy and it is considered as a metabolic (functional) image. These techniques are valuable in the early diagnosis of various diseases (Wen et al., 2007).

PET and SPECT procedures basically involve the administration of a radiopharmaceutical (radiobiocomplex) (Bernardo-Filho et al., 2005) that is selected for its ability to be localized with high uptake in the specific tumor site or target tissue. The radiobiocomplexes are molecular and cellular structures labeled with a specific radionuclide and are applied to patients after appropriate quality control. (Perkins, 2007). The image is formed by detection of the gamma rays or characteristic X-rays (SPECT) or the photonic energy emitted due to the annihilation of the positron (PET) as indicated in the Table 1. The images obtained provide a functional map of the whole distribution and uptake of the radiobiocomplex (Saha, 2004, Perkins, 2007; Fanti et al, 2007).

Table 1- General basis of the SPECT and PET imaging(*).

\begin{tabular}{ll}
\hline Technique & Basis \\
\hline SPECT & The gamma rays or characteristic X rays are emitted by the radionuclide that is fixed in the \\
& radioactivity is produced. In SPECT, the gamma camera rotates around the body of the patient \\
& and the image is reconstructed to produce image slices similar to a CT scan. \\
& A pair of photonic energy $(0.511 \mathrm{MeV})$ is produced due to the annihilation of the positron \\
& (antiparticle) in the presence of an electron. PET scanning uses a positron emitting tracer fixed in \\
the radiobiocomplex. The pair of photonic energy is detected by the PET scanner, recorded and \\
tomographic images of the tracer distribution in the body are reconstructed using mathematical \\
algorithms in a computer.
\end{tabular}

(*) adaptated from Perkins and Frier, 1999 and Perkins, 2007

An ideal PET or SPECT tracer for imaging prostate cancer (PC) would (i) identify both local and distant lesions, (ii) exhibit high target to nontarget uptake ratios, (iii) be easily available, (iv) be formulated by rapid and simple radiochemical syntheses, (v) be labeled with a radionuclide with favorable decay characteristics and (vi) have physical half-life of sufficient duration to allow to perform the clinical examination (Saha, 2004, Jana and Blaufox, 2006, Fanti et al, 2007).

SPECT uses the conventional radiobiocomplexes and a gamma camera is designed to rotate around the body of the patient (see Table 1). The name signifies that, at any instant in time, a single gamma photon (gamma emitter) or characteristic $\mathrm{X}$ rays ( $\mathrm{K}$ capture decay) is being detected. The 
data are reconstructed to form cross-sectional images in the same way as with $X$ ray $C T$ scanning. SPECT images may be recorded following conventional planar imaging without increasing the amount of radioactivity administered to the patient (Perkins, 2007). Table 2 shows the main radionuclides used to label radiopharmaceuticals used in the SPECT with their characteristics, such as decay, main photonic energy and physical half-life.

A particularly sensitive form of imaging known as PET scanning uses a positron emitting tracer fixed in the radiobiocomplex that is injected into the patient (Perkins and Frier, 1999; Perkins, 2007).

Table 2 - Main radionuclides used to label radiopharmaceuticals in SPECT.

\begin{tabular}{cccc}
\hline Radionuclide & Decay & $\begin{array}{c}\text { Main photon } \\
\text { energy (keV) }\end{array}$ & $\begin{array}{c}\text { Physical } \\
\text { half-life }\end{array}$ \\
\hline Technetium-99m $(99 \mathrm{mTc})$ & Gamma & 140 & 6 hours \\
Indium-111 $(111 \mathrm{In})$ & Gamma & 173 and 247 & 2.9 days \\
Iodine-123 $(123 \mathrm{I})$ & K capture & 160 & 13 hours \\
Iodine 131 $(131 \mathrm{I})$ & Beta minus and gamma & 360 & 8 days \\
Thalium-201 $(201 \mathrm{Tl})$ & K capture & 78 & 73.1 hours \\
\hline
\end{tabular}

(*) adapted from Perkins and Frier, 1999 and Perkins, 2007

PET has undergone explosive growth and demonstrated great potential for imaging many primary and metastatic cancers when compared with SPECT. Positron emitting radionuclides are produced in a cyclotron optimized for routine clinical use and they have a relatively short halflife (Table 3) (Saha, 2004; Jana and Blaufox, 2006; Perkins, 2007).

PET images are a volumetric set of data that can be displayed as tomographic images in the transaxial, coronal, or sagital planes. A limitation of PET is the lack of an anatomical reference frame whereas CT is an excellent morphological imaging modality with anatomical resolution. The combined PET/CT device offers optimal fusion of images, allowing the localization of functional findings detected by PET in morphological structures shown by CT during imaging (Perkins, 2007).

Table 3 - Half-live of radionuclide positron emitters used to PET scan (*).

\begin{tabular}{lc}
\hline Radionuclide & Physical half-life \\
\hline Fluorine-18 $(18 \mathrm{~F})$ & 110 minutes \\
Carbon-11 $(11 \mathrm{C})$ & 20 minutes \\
Nitrogen-13 $(13 \mathrm{~N})$ & 10 minutes \\
Oxygen-15 $(15 \mathrm{O})$ & 122 seconds \\
\hline
\end{tabular}

(*) adapted from Perkins and Frier, 1999, Perkins, 2007; Bouchelouche and Oehr, 2008

The aim of this brief review is to present some radiobiocomplexes that have been used in the clinical evaluation of male sexual organs (mainly testes, prostate and penis) related with male sexuality. This information could be valuable in better understanding the male sexual response cycle, as well as the sexual disorders, when considering the male sexual organs and the pelvic floor. Moreover, the findings obtained with PET and SPECT could complement the clinical results of therapeutic interventions.

\section{Radiopharmaceuticals used in the clinical evaluation of the testes}

Around the time of birth, and occasionally during the first weeks thereafter, the testes descend from the abdominal space to the scrotum through the processes vaginalis. Each hemiscrotum contains a testicle (ovoid form) measuring 3 to $5 \mathrm{~cm}$ in length and 2 to $3 \mathrm{~cm}$ in transverse and anteroposterior dimensions, and it is enveloped by a dense white fibrous capsule, the tunica albuginea (Jana and Blaufox, 2006; Futterer et al., 2008). The spectrum of conditions that affect the scrotum and its contents ranges from incidental findings and congenital anomalies to pathologic events that 
require rapid diagnosis and immediate treatment. Imaging of the scrotum (testes) is indicated when there is an acute situation with pain and swelling (Futterer et al., 2008). During sexual intercourse the scrotum exhibits characteristic modifications (Masters and Johnson, 1970; Kolodny et al., 1979).

Nuclear medicine studies have been used to evaluate the acute scrotum (testicular torsion versus epididymoorchitis) and testicular tumors (initial staging of cancer, recurrent/residual disease and monitor the treatment response) ((Jana and Blaufox, 2006; Futterer et al., 2008).

The radiopharmaceuticals used in the clinical evaluations of disorders of the testes are shown in Table 4.

\section{Radiopharmaceuticals used in the clinical evaluation of the prostate}

The prostate is a small gland with the size and shape of a large chestnut; it surrounds the first 1.25 inch of the male urethra, proximal to the sphincter of the bladder (Jana and Blaufox, 2006). Imaging procedures can be valuable in aiding the clinical evaluation of the prostate. Furthermore, the images of the prostate are highly relevant because of its involvement in many male disorders.

Table 4 - Radiopharmaceuticals used in the clinical evaluations of the testes.

\begin{tabular}{lcll}
\hline Radiopharmaceutical & $\begin{array}{c}\text { Nuclear } \\
\text { medicine procedure }\end{array}$ & \multicolumn{1}{c}{ Clinical use } & Reference \\
99mTc-pertechnetate & SPECT & $\begin{array}{l}\text { To differentiate acute testicular torsion } \\
\text { versus from epididymoorchitis }\end{array}$ & $\begin{array}{l}\text { Kim et al, 1993 } \\
\text { Jana and Blaufox, } \\
2006\end{array}$ \\
Gallium-67 citrate & SPECT & $\begin{array}{l}\text { To evaluate testicular cancer and to } \\
\text { stage lymph node metastases }\end{array}$ & $\begin{array}{l}\text { Willan et al, } \\
1987, \\
\text { Warren, 1995 }\end{array}$ \\
18F-FDG & PET & $\begin{array}{l}\text { To detect initial staging of cancer, } \\
\text { recurrent/residual disease and to } \\
\text { monitor treatment response in } \\
\text { testicular cancers. }\end{array}$ & $\begin{array}{l}\text { Ganjoo et al, } \\
\text { 1999 }\end{array}$ \\
\hline
\end{tabular}

However, a number of problems have prevented success in its exploration, such as the size and location of the prostate. The small size and location deep within the pelvis interferes with the accurate detection of diseases with noninvasive imaging, particularly at the early stages. The other problem for nuclear medicine imaging of the prostate is the proximity of the urinary bladder. Most radiopharmaceuticals are primarily excreted by the kidneys, resulting in bladder activity that obscures the prostate (Jana and Blaufox, 2006, Futterer et al., 2008).

The prostate changes and commonly enlarges with age. The most frequent types of prostate diseases are prostatitis, benign prostatic hyperplasia $(\mathrm{BPH})$, and PC. PC is the most common malignancy in men in several countries (Jemal et al.., 2007). Table 5 shows radiopharmaceuticals used in the clinical evaluations of disorders of the prostate.

Radiopharmaceuticals used in the clinical evaluation of the seminal vesicles, urethra, penis and pelvic floor muscles
The two seminal vesicles (SV) resemble small, bulbous pouches and are located just above the prostate. SV are directly connected to the vas deferens, which transports sperm to them before ejaculation. SV make up the bulk of the ejaculatory fluid. After adding fluid to the sperm, the liquid is transported to the prostate gland. Removal of the SV during PC treatment, along with the prostate gland in radical prostatectomy, can cause dry orgasm. SV cyst, tuberculous vesiculitis, adenocarcinoma of the SV, neurilemmoma of the SV, phyllodes tumor of the prostate, and rhabdomyosarcoma of the SV are some diseases related to the SV (Kumar et al, 2005, Futterer et al., 2008).

The penis is the male genital organ which carries the duct, the urethra, for the emission of sperm and ejection of urine. The penis can be affected by congenital anomalies, inflammations, and tumors (both benign and malignant). The urethra is a membranous canal which leads from the bladder to the outside of the body and the penis is associated with it. Inflammations, tumors and tumor-like 
lesions are found in the urethra (Kumar et al, 2005).

The pelvic floor (PF) muscles are associated with various organs and are the support of the pelvic organs. Pelvic inflammatory disease can be found in the $\mathrm{PF}$ and is characterized by pelvic pain. Like all other organs in the chest or abdominal cavities, pelvic organs are not suspended by specialized ligaments such as those in the skeletomuscular system. In spite of this, the organs of the pelvis remain well suspended within their cavity even during evacuation. The support system for these organs consists of inconspicuous smooth muscle elements scattered throughout pelvic structural fat tissues and facial structures, in particular Denonvilliers' fascia (Stelzner et al., 2005).

Table 6 shows some radiopharmaceuticals used in the clinical evaluations of disorders associated with SV, penis and PF muscles.

Table 5 - Radiopharmaceuticals used in the clinical evaluations of the prostate.

\begin{tabular}{|c|c|c|c|}
\hline Radiopharmaceutical & $\begin{array}{l}\text { Nuclear medicine } \\
\text { procedure }\end{array}$ & Clinical use & Reference \\
\hline 99mTc-colloid & SPECT & $\begin{array}{l}\text { To perform lymphoscintigraphy and to } \\
\text { assess the laterality of lymphatic } \\
\text { drainage of the prostate, before total } \\
\text { prostatectomy with pelvic node } \\
\text { resection }\end{array}$ & $\begin{array}{l}\text { Zuckier et al, 1990, } \\
\text { Jana and Blaufox, } \\
2006\end{array}$ \\
\hline 99TcMDP & SPECT & To evaluate bone metastases & $\begin{array}{l}\text { Gerber and Chodak, } \\
1991\end{array}$ \\
\hline $\begin{array}{l}\text { 111In-prostascint (murine } \\
\text { monoclonal antibody) }\end{array}$ & SPECT & $\begin{array}{l}\text { To evaluate nodal recurrence when } \\
\text { bone scan is negative }\end{array}$ & Lange , 2001 \\
\hline 18F-FDG & PET & It is not very useful. & $\begin{array}{l}\text { Jana and Blaufox, } \\
\text { 2006, Fanti et al, } 2007\end{array}$ \\
\hline $11 \mathrm{C}$-Acetate $(*)$ & PET & $\begin{array}{l}\text { To evaluate local disease, nodal } \\
\text { metastases and distant metastases due } \\
\text { to the low urinary excretion. }\end{array}$ & Kotzerke et al, 2002 \\
\hline $18 \mathrm{~F}$-Acetate $(* *)$ & PET & Limited clinical data & $\begin{array}{l}\text { Jana and Blaufox, } \\
2006\end{array}$ \\
\hline 11C-Choline $(*)$ & PET & $\begin{array}{l}\text { To evaluate local disease, nodal } \\
\text { metastases and distant metastases due } \\
\text { to the low urinary excretion. }\end{array}$ & $\begin{array}{l}\text { Kotzerke et al, } 2000 \\
\text { Roivainen et al, } 2000\end{array}$ \\
\hline 18F-Choline $(* * *)$ & PET & $\begin{array}{l}\text { To evaluate local disease, nodal } \\
\text { metastases and distant metastases. }\end{array}$ & $\begin{array}{l}\text { Jana and Blaufox, } \\
2006\end{array}$ \\
\hline 11C-Methionine $(*, * *)$ & PET & $\begin{array}{l}\text { It would be useful for evaluating } \\
\text { recurrent disease. }\end{array}$ & Toth et al, 2007 \\
\hline $\begin{array}{l}18 \text { F-Fluoride bone } \\
\text { Scan }\end{array}$ & PET & $\begin{array}{l}\text { Slightly more accurate than } \\
99 \text { mTc-MDP bone particularly with } \\
\text { CT in a PET/CT scanner, however, no } \\
\text { effective }\end{array}$ & $\begin{array}{l}\text { Jana and Blaufox, } \\
2006\end{array}$ \\
\hline $\begin{array}{l}\text { 18F-Fluoro- } \\
\text { dihydrotestoterone }(* *)\end{array}$ & PET & $\begin{array}{l}\text { To monitor treatment response } \\
\text { possibility with } 18 \mathrm{~F}-\mathrm{FDG} \text { to } \\
\text { Evaluate the androgen insensitivity }\end{array}$ & $\begin{array}{l}\text { Jana andd Blaufox, } \\
2006\end{array}$ \\
\hline 99mTc-ciprofloxacin & SPECT & $\begin{array}{l}\text { It would be useful to evaluate } \\
\text { Chronic bacterial prostatitis. }\end{array}$ & Ryu et al, 2003 \\
\hline
\end{tabular}

(*) The major obstacle for routine used of the radiopharmaceutical labeled with 11C is its short half-life (20 min), (**) Limited clinical data, $(* * *)$ Better than $18 \mathrm{~F}-\mathrm{FDG}$, less urinary excretion and longer half-life of $18 \mathrm{~F}$ compared to $11 \mathrm{C}$. 
Table 6 - Radiopharmaceuticals used in the clinical evaluations of the seminal vesicles, urethra, penis and pelvic floor muscles.

\begin{tabular}{|c|c|c|c|c|}
\hline Radiopharmaceutical & $\begin{array}{c}\text { Nuclear medicine } \\
\text { procedure }\end{array}$ & $\begin{array}{l}\text { Anatomic } \\
\text { Structure }\end{array}$ & Clinical use & Reference \\
\hline 99mTc ciprofloxacin & SPECT & Seminal vesicles & seminal vesiculitis & Choe et al, 2003 \\
\hline $\begin{array}{l}\text { 99mTc-sulphur } \\
\text { colloid }\end{array}$ & SPECT & Seminal vesicle & $\begin{array}{l}\text { Evaluation of partial and } \\
\text { complete ejaculatory } \\
\text { obstruction }\end{array}$ & Orphan et al, 2008 \\
\hline 18F-FDG & PET & Penis & penile cancer & Halac et al, 2007 \\
\hline 99mTc- nanocolloid & SPECT & Penis & $\begin{array}{l}\text { sentinel node }(\mathrm{SN}) \\
\text { identification } \mathrm{SN} \\
\text { in carcinoma of the penis }\end{array}$ & $\begin{array}{l}\text { Valdés Olmos } \\
\text { et al, } 2001\end{array}$ \\
\hline $\begin{array}{l}\text { 99mTc-labeled Red } \\
\text { Blood Cells }\end{array}$ & SPECT & Penis & $\begin{array}{l}\text { method for the } \\
\text { objective differentiation }\end{array}$ & $\begin{array}{l}\text { Shen and Kao, } \\
1998\end{array}$ \\
\hline $\begin{array}{l}\text { Blood pool labeled } \\
\text { with } 99 \mathrm{mTc}\end{array}$ & SPECT & Penis & $\begin{array}{l}\text { among psychogenic, } \\
\text { arteriogenic, and } \\
\text { venogenic impotence. } \\
\text { screening test for } \\
\text { vasculogenic impotence }\end{array}$ & $\begin{array}{l}\text { Timmermans, } \\
1998\end{array}$ \\
\hline 18F-FDG & PET & $\begin{array}{l}\text { muscle activity } \\
\text { in the pelvis }\end{array}$ & $\begin{array}{l}\text { Studies to identify } \\
\text { spontaneous muscle } \\
\text { activity in the pelvis, } \\
\text { which is strongest at } \\
\text { Denonvilliers' fascia. }\end{array}$ & $\begin{array}{l}\text { Stelzner et al, } \\
2005\end{array}$ \\
\hline
\end{tabular}

\section{DISCUSSION}

Sexuality is an important component of emotional and physical intimacy that men and women experience throughout their lives (Camacho and Reyes-Ortiz, 2005). The sexual dysfunctions are differentiated according to the sexual response cycle (Beutel et al., 2006): desire (hypoactive sexual desire disorder/sexual aversion), arousal (male erectile disorder), orgasm (male orgasmic disorder, premature ejaculation). Dyspareunia is painful sensations that can occur during or following the sexual activity. Sexual deviance (paraphilia) includes exhibitionism, fetishism, pedophilia, masochism, sadism, and voyeurism. Gender identity disorders refer to the conviction of living in a body with the wrong gender and the wish to adopt the "right" gender (transsexuality). Various physiological and clinical conditions associated with the human male psychosexual cycle have been evaluated with imaging modalities (Sumich et al, 2003).

Nuclear medicine images include SPECT and PET and permit the visualization of subtle changes in the physiological function in vivo. These findings aid the early diagnosis of various diseases (Wen et al., 2007). Furthermore, some aspects of sexual activity have been studied both with SPECT
(Tiihonen et al., 1994) and PET (Rauch et al., 1999; Stoleru et al., 1999; Redoute et al., 2000).

Concerning the prostate and the testis, a variety of radiopharmaceuticals have been used to evaluate several clinical disorders and complications (Tables 4 and 5) and important findings have helped to characterize the diseases as well as the consequences of the various possible treatments, such as surgery, medications, and physiotherapy. An important observation (see Table 4) is that, although the 18F-FDG has been widely used in the PET scans for various types of cancer, in the case of PC, this radiopharmaceutical is not very useful (Jana and Blaufox, 2006).

Considering the SV, penis and PF muscles, the use of the nuclear medicine techniques is still limited. However, some studies have revealed the relevance of these techniques in the clinical evaluation of the penis and SV (Halac et al. 2007). Choe et al, 2003 have reported the use of the Tc$99 \mathrm{~m}$ ciprofloxacin SPECT imaging of a patient with prostatitis syndrome, in whom seminal vesiculitis was finally diagnosed. Orhan et al. (2008) have defined a novel technique in the diagnosis of partial and complete ejaculatory duct obstruction (EDO). Men with suspected EDO were initially evaluated by transrectal ultrasound (TRUS). Subsequently, all patients underwent 
TRUS-guided SV scintigraphy. 99mTc sulphur colloid solution was injected into each SV under TRUS guidance and patients were immediately investigated by scintigraphy. After patients ejaculated, scintigraphy was repeated. The difference between the two measurements with respect to the technetium-99m count was used to measure the percentage of emptying. The authors concluded that SV scintigraphy is unique in that it incorporates the physiologic aspect of ejaculation into a diagnostic intervention, which the authors believe is especially important in the diagnosis of functional EDO.

Halac et al. (2007) have demonstrated, in patients with penile cancer, the relevance of the 18F-FDG PET for identifying metastatic lesions and for therapeutic strategy planning. Moreover, Ravizzini et al. (2001) have reported early on the importance of the 18F-FDG in the detection of metastatic penile squamous cell carcinoma. Valdés Olmos et al. (2001) have evaluated the findings of lymphoscintigraphy for sentinel node (SN) identification in penile carcinoma. It is concluded that penile lymphoscintigraphy is a valid and welltolerated method for lymphatic mapping and SN identification. The SN identification may lead to more accurate staging and avoid extensive lymph node dissection in the majority of patients with penile carcinoma. Shen and Kao (1998) have used the $99 \mathrm{mTc}$-labeled RBC erection penogram (TcRBC penogram) coupled with intracavernosal injection of prostaglandin to evaluate the penile hemodynamic changes during tumescence. They conclude that the Tc-RBC penogram is a simple, noninvasive, and valuable method for the objective differentiation among psychogenic, arteriogenic, and venogenic erectile dysfunction. Timmermans, 1998 reported that the radioisotope erection penogram is a noninvasive, reproducible, and reliable screening test for the evaluation of vasculogenic erectile dysfunction.

The organs of the male reproductive tract are also closely involved with the sexual activity and clinical disorders of these organs could also contribute to the impairment of the normal response of the cycle of sexual activity. Thus, they have also been studied using imaging techniques based on the use of radiopharmaceuticals (Fanti et al., 2007, Futterer et al., 2008).

In conclusion, the knowledge acquired using nuclear medicine imaging of the male reproductive tract could aid in better understanding the physiology of the different organs related with sexuality. Moreover, they are important tools in evaluating the physiological integrity of the organs involved and improving the clinical strategies for patients under treatment with medication and/or psycho-sexual and physiotherapeutic strategies.

\section{ACKNOWLEDGMENTS}

The authors thank CAPES, CNPq, UERJ, INCA and FAPERJ for the financial support.

\section{RESUMO}

A sexualidade consiste de três aspectos que são inter-relacionados e inseparáveis: biólogico, fisiológico e social. O aspecto biológico considera a capacidade individual de dar e receber prazer. Em consequência, envolve a funcionalidade dos órgãos sexuais e a fisiologia do ciclo da resposta sexual humana. As imagens cintilográficas single photon emission computed tomography (SPECT) e positron emission tomography (PET) têm sido usadas para avaliar comprometimentos clínicos do sistema reprodutor masculino. Os procedimentos PET e SPECT envolvem a administração de um radiofármaco que é selecionado pela sua abilidade de ser captado em um específico tumor ou tecido. O objetivo dessa pequena revisão é apresentar os radiofármacos que têm sido empregados na avaliação clínica de órgãos sexuais masculinos (testículos, prostáta, vesícula seminal, pênis) relacionados com a sexualidade masculina. Essa informação poderia ajudar a entender melhor a resposta sexual masculina, assim como as disfunções associdas com os órgãos sexuais masculinos e do assolho pélvico. Mais ainda, os achados clínicos obtidos com o PET e SPECT poderiam contribuir para avaliar a eficácia dos procedimentos terapêuticos. Em conclusão, a aplicação das imagens obtidas pelas técnicas da medicina nuclear na avaliação dos órgãos do sistema reprodutivo masculino poderia contribuir para uma melhor compreensão da fisiologia dos diferentes órgãos relacionados com a sexualidade. Essas imagens poderiam ser importante ferramenta na avaliação da fisiologia dos órgãos relacionados, para melhorar as estratégicas clínicas e para acompanhar os pacientes em tratamento medicamentoso ou psico-sexual ou fisioterapeutico. 


\section{REFERENCES}

Bernardo-Filho, M.; Santos-Filho, S. D.; Moura, E. G.; Maiworm, A. I.; Orlando, M. M. M. C.; Penas, M. E.; Cardoso, V. N.; Bernardo, L. C.; Brito, L. (2005), Drug interaction with radiopharmaceuticals: a review. Braz Arch Biol Technol., 48, 13-27.

Beutel, M. E.; Weidner, W.; Brahler, E. (2006). Epidemiology of sexual dysfunction in the male population. Andrologia. 38:115-121.

Bouchelouche, K.; Oehr, P. (2008), Positron emission tomography and positron emission tomography/computerized tomography of urological malignancies: an update review. J Urol., 179, 34-45.

Chaffanjon, P. C.; Sturm, N.; Caravel, J. P.; Chabre, O.; Brichon, P. Y. (2004), Pelvic muscular metastasis of well differentiated thyroid carcinoma. Ann Chir., 129, 100-102.

Choe, W.; Kan Ryu, J.; Kim, W. H.; Chung, M. H.; Suh, J. K. (2003), Imaging seminal vesiculitis with Tc-99m ciprofloxacin. Clin Nucl Med., 28, 501-502

Dennerstein, L.; Lehert, P.; Burger, H.; Guthrie, J. (2005), Sexuality. Am J Med., 118, 59S-63S.

Fanti, S.; Nanni, C.; Ambrosini, V.; Gross, M. D.; Rubello, E.; Farsad, M. (2007), Positron tomography in genitourinary tract cancers. $Q \mathrm{~J} \mathrm{Nucl} \mathrm{Med} \mathrm{Mol}$ Imaging., 51, 1-12.

Ganjoo, K. N.; Chan, R. J.; Sharma, M.; Einhorn, L. H. (1999), Positron emission tomography scans in the evaluation of postchemotherapy residual masses in patients with seminoma. J Clin Oncol., 17, 34573460 .

Gerber, G.; Chodak, G. W. (1991), Assessment of value of routine bone scans in patients with newly diagnosed prostate cancer. Urology., 37, 418-422.

Halac, M.; Zincirkeser, S.; Sönmezoglu, K.; Sager, S.; Durak, H.; Uslu, I. (2007), Fluoro-18 fluorodeoxyglucose positron emission tomography/computerized tomography scans in a patient with penile cancer for appropriate therapeutic strategy. Hell J Nucl Med., 10, 113-115.

Hatzimouratidis, H.; Hatzichristou, D. (2007), Sexual dysfunctions: classifications and definitions. J Sex Med., 4, 241-250

Jana, S.; Blaufox, D. (2006), Nuclear medicine studies of the prostate, testes and bladder. Semin Nucl Med., 36, 51-72.

Kim, C. K.; Zuckier, L. S.; Alavi, A. (1993), The role of nuclear medicine in the evaluation of male genital tract. Semin Roentgenol., 28, 31-42.

Kolodny, R. C.; Masters, W. H.; Johnson, V. E. (1979), Textbook of Sexual Medicine, Boston, Little, Brown.

Kotzerke, J.; Prang, J.; Neumaier, B.; Volkmer, B.; Guhlmann, A.; Kleinschmidt, K.; Hautmann, R.; Reske, S. N. (2000), Experience with carbon-11 choline positron emission tomography in prostate carcinoma. Eur J Nucl Med., 27, 1415-1419.
Kotzerke, J.; Volkmer, B. G.; Neumaier, B.; Gschwend, J. E.; Hautmann, R. E.; Reske, S. N. (2002), Carbon11 acetate positron emission tomography can detect local recurrence of prostate cancer. Eur J Nucl Med Mol Imaging., 29, 1380-1384.

Kumar, V.; Abbas, A. K.; Fausto, N.. Robbins and Cotran Pathologic Basis of Disease. Elsevier Saunders, Pennsylvania (2005).

Lange, P. H. (2001), Prostascint scan for staging prostate cancer. Urology., 57, 402-406.

Masters, W. H.; Johnson, V. E. (1970), Humanly Sexual Inadequacy, Boston, Little, Brown.

Orhan, I.; Duksal, I.; Onur, R.; Balci, T. A.; Poyraz, K.; Firdolas, F.; Kadioglu, A. (2008), Technetium Tc 99m Sulphur Colloid Seminal Vesicle Scintigraphy: A Novel Approach for the Diagnosis of the Ejaculatory Duct Obstruction. Urology., 71, 672-676.

Perkins, A. (2007), Tumour imaging and therapy. In The Cancer Clock, Missailidis S. (Editor). John Wiley and Sons, West Sussex.

Perkins, A.; Frier, M. (1999), Nuclear Medicine in Pharmaceutical Research. Taylor and Taylor Ltd, London.

Ravizzini, G.; Wagner, M.; Borges-Neto, S. (2001), Positron emission tomography detection of metastatic penile squamous cell carcinoma. J Urol., 165, 16331634.

Roivainen, A.; Forsback, S.; Grönroos, T.; Lehikoinen, P.; Kähkönen, M.; Sutinen, E.; Minn, H. (2000), Blood metabolism of [methyl-11C]choline; implications for in vivo imaging with positron emission tomography. Eur J Nucl Med., 27, 25-32.

Ryu, J.; Lee, S.; Seong, D.; Suh, J.; Kim, S.; Choe, W.; Moon, Y.; Pai, S. (2003), Tc-99m ciprofloxacin imaging in diagnosis of chronic bacterial prostatitis. Asian J Androl., 5, 79-83.

Saha G. Fundamentals of Nuclear Pharmacy, Springer Verlag, New York, 2004.

Shen, Y. Y.; Kao, C. H. (1998), Technetium-99mlabelled RBC erection penogram to differentiate psychogenic from vasculogenic impotence. Urol Int., 61, 27-31.

Stelzner, F.; Biersack, H. J.; von Mallek, D.; Reinhardt, M. (2005), PET-CT studies of the support system and continence function of pelvic organs. The pivotal importance of Denonvilliers' fascia for surgical procedures. Chirurg., 76, 1168-1174.

Sumich, A. L.; Kumari V.; Sharma, T. (2003), Neuroimaging of sexual arousal: research and clinical utility. Hospital Medicine, 64, 28-33.

Timmermans, L. (1998), Methodology of penile isotope imaging. Evaluation. Acta Urol Belg., 66, 13-17.

Tóth, G.; Lengyel, Z.; Balkay, L.; Salah, M. A.; Trón, L.; Tóth, C. (2005), Detection of PCwith 11Cmethionine positron emission tomography. J Urol., 173, 66-69. 
Valdés Olmos, R. A.; Tanis, P. J.; Hoefnagel, C. A.; Jansen, L.; Nieweg, O. E.; Meinhardt, W.; Horenblas, S. (2001), Penile lymphoscintigraphy for sentinel node identification. Eur J Nucl Med., 28, 581-585.

Warren, G. P. (1995), Gallium scans in the evaluation of residual masses after chemotherapy of seminoma. J Clin Oncol., 13, 2784-2788.

Willan, B. D.; Penney, H.; Castor, W. R.; McGowan, D. G. (1987), The usefulness of gallium-67 citrate scanning in testicular seminoma. Clin Nucl Med., 12, 813-815.
Zuckier, L. S.; Finkelstein, M.; Kreutzer, E. R.; Stone, P. L.; Freed, S. Z.; Bard, R. H.; Blaufox, M. D.; Freeman, L. M. (1990), Technetium-99m antimony sulphide colloid lymphoscintigraphy of the prostate by direct transrectal injection. Nucl Med Com, 11, 589-596.

Received: August 18, 2008; Revised: September 11, 2008; Accepted: September 15, 2008. 